\title{
Iron oxyhydroxide and sulphide mineralization in hydrocarbon seep-related carbonate submarine chimneys, Gulf of Cadiz (SW Iberian Peninsula)
}

\author{
R. Merinero ${ }^{\mathrm{a}, *}$, R. Lunar ${ }^{\mathrm{a}}$, J. Martínez-Frías ${ }^{\mathrm{b}}$, L. Somoza ${ }^{\mathrm{c}}$, V. Díaz-del-Río $^{\mathrm{d}}$ \\ ${ }^{a}$ Crystallography and Mineralogy Department, Universidad Complutense de Madrid (UCM), c/ José Antonio Novais 2, Ciudad Universitaria, 28040 Madrid, Spain \\ b Planetary Geology Laboratory, Centro de Astrobiología (CSIC/INTA), Associated to the NASA Astrobiology Institute, Crta. Ajalvir, km. 4, 28850 Torrejón de Ardoz, Madrid, Spain \\ ${ }^{\mathrm{C}}$ Marine Geology Division, Geological Survey of Spain (IGME), c/ Ríos Rosas 23, 28003 Madrid, Spain \\ ${ }^{d}$ Malaga Oceanographic Centre, Instituto Español de Oceanografía (IEO), Apdo. 285, 29640 Fuengirola (Malaga), Spain
}

Keywords:

Gulf of Cadiz

Pyrite goethite framboid

Methane carbonate

\begin{abstract}
A B S T R A C T
This paper aims to investigate the iron mineralization hosted in the submarine hydrocarbon seep-related carbonate chimneys, from the Gulf of Cadiz continental slope (SW Iberia). Chimneys are made of a general fine groundmass of major Fe-rich dolomite, ankerite and calcite, small grains of quartz and phyllosilicates, and some foraminifer tests and ostracod shells. Primary porosity is frequently generated inside foraminifer chambers and ostracod shells, and is filled with closely packed microcrystals of iron oxyhydroxide and sulphide minerals forming framboids. Some extremely peculiar multiframboidal textures are also detected, corresponding to microcrystal groups, spherical framboids and euhedral crystals without framboidal texture. The mineralogy observed is mainly goethite (pyrite pseudomorphs); traces of tiny grains of pyrite were also observed. Cubic, octahedral and pyritohedral are the habits observed in both minerals. Chemical analyses of framboids and euhedral crystals display high (often erratic) amounts of $\mathrm{As}, \mathrm{Co}, \mathrm{Ni}$ and $\mathrm{Mo}$ in oxyhydroxides and $\mathrm{Mo}, \mathrm{Pb}, \mathrm{V}$ and $\mathrm{Co}$ in sulphides versus almost always negligible concentrations of $\mathrm{Cu}$ and $\mathrm{Zn}$. A textural, geochemical and mineralogical evolution is proposed to explain the coexistence of different morphologies in the multiframboidal texture: (a) growth and aggregation of microcrystals as typical framboidal-type mineralogical associations; (b) development of euhedral habits; (c) coalescence and homogenization of the microcrystal into large size (euhedral to anhedral) crystals, and (d) formation of euhedral crystals or polycrystalline masses, with complete loss of framboidal texture. Along this process, an increase of the concentration of $\mathrm{Fe}, \mathrm{S}, \mathrm{Mn}$ and $\mathrm{Ti}$, linked to a decrease in $\mathrm{Mg}, \mathrm{Si}, \mathrm{Al}, \mathrm{As}, \mathrm{P}, \mathrm{Ca}$ and $\mathrm{V}$ was observed. The study of the iron mineralization in the Gulf of Cadiz is a first, and can give clues to understand the complex geobiological interactions in this and other similar extreme hydrocarbon-bearing submarine ecosystems.
\end{abstract}

\section{Introduction}

Marine cold seeps and methane vents are common features of continental margins and other geodynamic settings worldwide (see Paull and Neumann, 1987; Brooks et al., 1991; Ivanov et al., 1991; Whiticar and Werner, 1991; Jørgensen, 1992; Laier et al., 1992; De Angelis et al., 1993; Dando et al., 1994; Paull et al., 1995; Boehme et al., 1996; Cable et al., 1997; Orpin, 1997; Stakes et al., 1999; DeLong, 2000; Paull et al., 2005, among others) with no elevated temperatures, where methane-rich fluids flow through the continental crust and are colonized by large communities of microbial and chemosynthetic organisms. Methane is generated from various sources: thermogenic and biogenic methane and decomposing

\footnotetext{
* Corresponding author. Tel.: +34 1 3944959; fax: +34 13944872

E-mail address: rmeriner@geo.ucm.es (R Merinero).
}

methane hydrates, and is seeping to the hydrosphere and potentially to the atmosphere. Cold seeps are associated with authigenic carbonates building chemoherms (e.g. Bohrmann et al., 1998, 2002; Suess et al., 1998; Naehr et al., 2000; Pierre et al., 2000; Peckmann et al., 2001; Thiel et al., 2001; Aloisi et al., 2002; Hübscher and Kukowski, 2003; Han et al., 2004; Teichert et al., 2005, among others) that resemble reefs and/or chimneys (Shnukov et al., 1995; Orpin, 1997; Stakes et al., 1999; Michaelis et al., 2002; Gulin et al., 2003).

Iron sulphide precipitation is often associated with these microbially mediated carbonates. The anaerobic oxidation of methane (AOM) in anoxic marine sediments is directly linked to sulphate reduction (Barnes and Goldberg, 1976; Nauhaus et al., 2002; Valentine, 2002), through a syntrophic interaction between methanogenic archaea and sulphate-reducing bacteria (e.g. Hoehler et al., 1994; Elvert et al., 1999, 2000; Hinrichs et al., 1999, 2000; Thiel et al., 1999, 2001; Boetius et al., 2000; Pancost et al., 2000, 2001; 
Table 1

Major and trace element analyses of carbonate chimney samples (results are in ppm)

\begin{tabular}{|c|c|c|c|c|c|c|c|c|c|c|c|c|c|c|c|c|c|c|c|c|c|}
\hline Sample & $\mathrm{Si}$ & $\mathrm{Al}$ & $\mathrm{Fe}$ & $\mathrm{Ca}$ & $\mathrm{Ti}$ & $\mathrm{Mn}$ & K & $\mathrm{Mg}$ & $\mathrm{P}$ & $\mathrm{Ja}$ & $\mathrm{Sr}$ & $\mathrm{Ba}$ & V & As & $\mathrm{Zr}$ & $\mathrm{Cr}$ & $\mathrm{Zn}$ & $\mathrm{Ni}$ & Sc & $\mathrm{Rb}$ & Co \\
\hline 0 & 909 & 21117 & 403 & 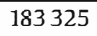 & 1415 & 736 & 400 & 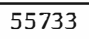 & 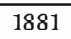 & & 49 & 16 & 2 & 143 & 73 & & 74 & 8 & 31 & 27 & $\overline{40}$ \\
\hline 00 & 45735 & 166 & 103 & 180 & 10 & 596 & 4707 & 4 & 15 & & & & & & & & & & & & \\
\hline 01 & 40083 & 17624 & 98 & 17 & 1061 & 929 & 4740 & 73 & 1471 & 30 & 386 & 128 & $2 J 2$ & 147 & 53 & 43 & 60 & 40 & ונה & 23 & 41 \\
\hline 260011 & 44660 & 18312 & 51617 & 191640 & 1079 & 604 & 5122 & 82801 & 1296 & & 892 & 267 & 147 & 85 & 46 & & 42 & 27 & & 26 & 1 \\
\hline 822 & 6471 & 22 & 32 & & 12 & 263 & 5 & 49 & & & 990 & 11 & 80 & . & 72 & 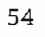 & 28 & 17 & 31 & 28 & \\
\hline 15070093-AN01 & 92829 & 32550 & 59090 & 172783 & 1283 & 612 & 6152 & 51954 & 1942 & 4518 & 552 & 165 & 118 & 74 & 82 & 75 & 37 & 26 & 27 & 28 & 19 \\
\hline
\end{tabular}

Valentine and Reeburgh, 2000; Bian et al., 2001; Lanoil et al., 2001; Orphan et al., 2001, 2002; Thomsen et al., 2001; Hinrichs and Boetius, 2002; Michaelis et al., 2002; Teske et al., 2002; Zhang et al., 2002). This biogeochemical process is represented by the net reaction:

$$
\mathrm{CH}_{4}+\mathrm{SO}_{4}^{2-} \rightarrow \mathrm{HCO}_{3}^{-}+\mathrm{HS}^{-}+\mathrm{H}_{2} \mathrm{O}
$$

In marine methane seeps, the process of $A O M$ and resulting $\mathrm{HCO}_{3}^{-}$production is thought to foster carbonate formation through localized increases in alkalinity (e.g. Ritger et al., 1987; Paull et al., 1992; Sassen et al., 2004). Hydrogen sulphide can combine with iron and other elements retained in walls and covers of bacteria cells, favouring the precipitation of pyrite and other iron sulphides. Framboidal texture (basically a spherical packed aggregate of microcrystals) is one of the principal occurrences of pyrite in sedimentary environments (Chauhan, 1974; Elverhoi, 1977; Sawlowicz, 1993; Wilkin and Barnes, 1997; Butler and Rickard, 2000; Schoonen, 2004). Pyrite, as well as other iron sulphides and oxyhydroxides, presents framboidal texture in a broad range of conditions, from hydrothermal deposits (Martínez-Frías et al., 1997) to magmatic (Love and Amstutz, 1969) and metamorphic rocks (Schieber and Baird, 2001; Boyle et al., 2003), even in ancient books and fossil wood (García-Guinea et al., 1997, 1998). Pyrite framboids often occur in close spatial relationship with organic matter, silica or carbonates, which influence their formation and growth, containing organic matter both in their interstices and/or as membranes coating framboids (Love and Amstutz, 1966; Sweeney and Kaplan, 1973; Taylor, 1982; Sawlowicz, 2000).

The term "polyframboid" was suggested by Love (1971) and represents aggregates of framboid units with the same size. Multiframboids are more complex textures (Massaad, 1974; Roberts et al., 2005; Merinero et al., 2005, 2006), characterized by a mixture of crystal sizes and morphologies (microcrystals, subspherical framboids and euhedral crystals). Availability of space and nutrients (sulphur, iron and other metals) are necessary for the polyframboid formation.
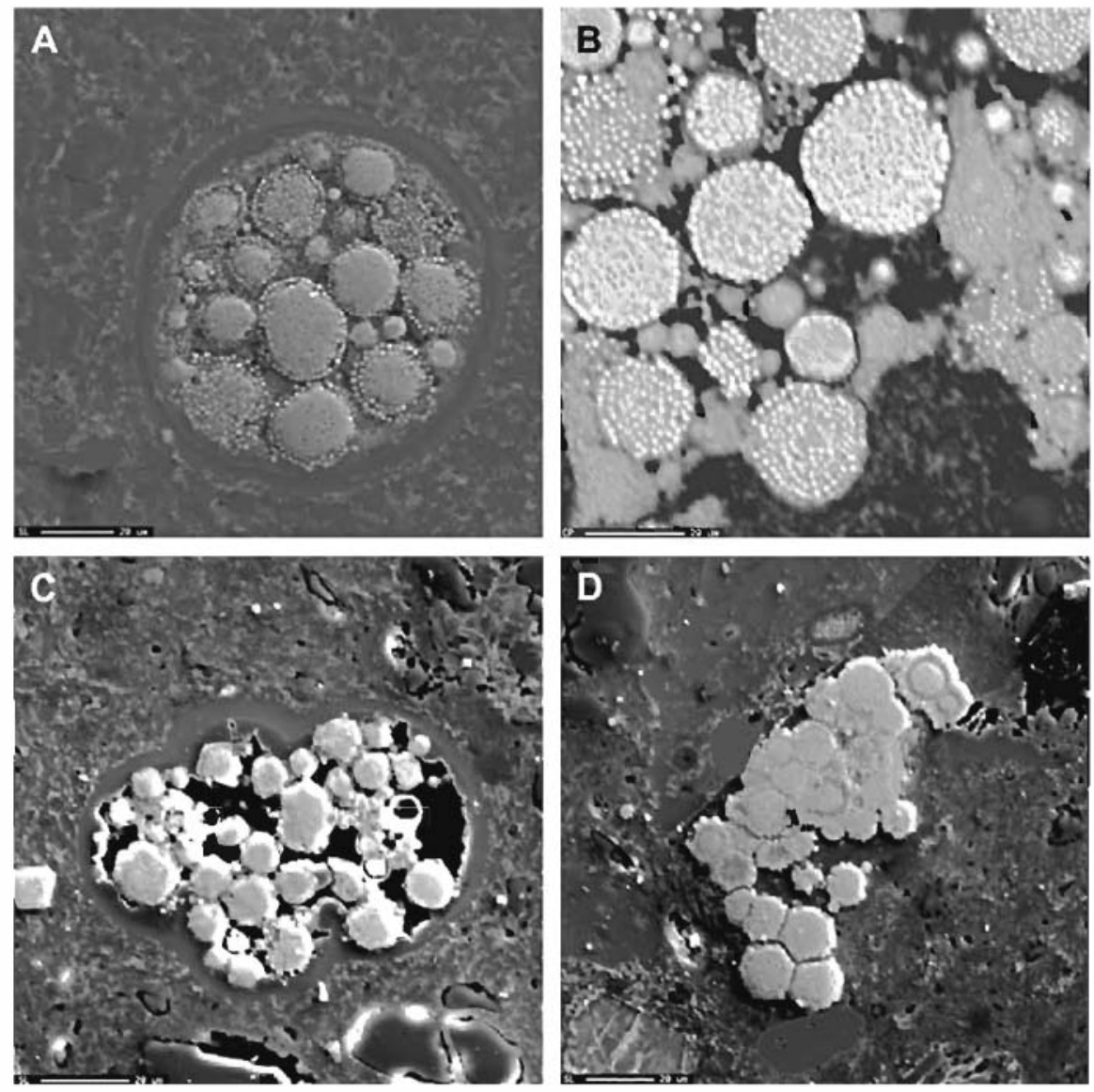

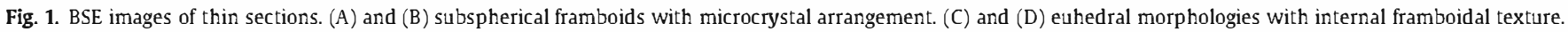



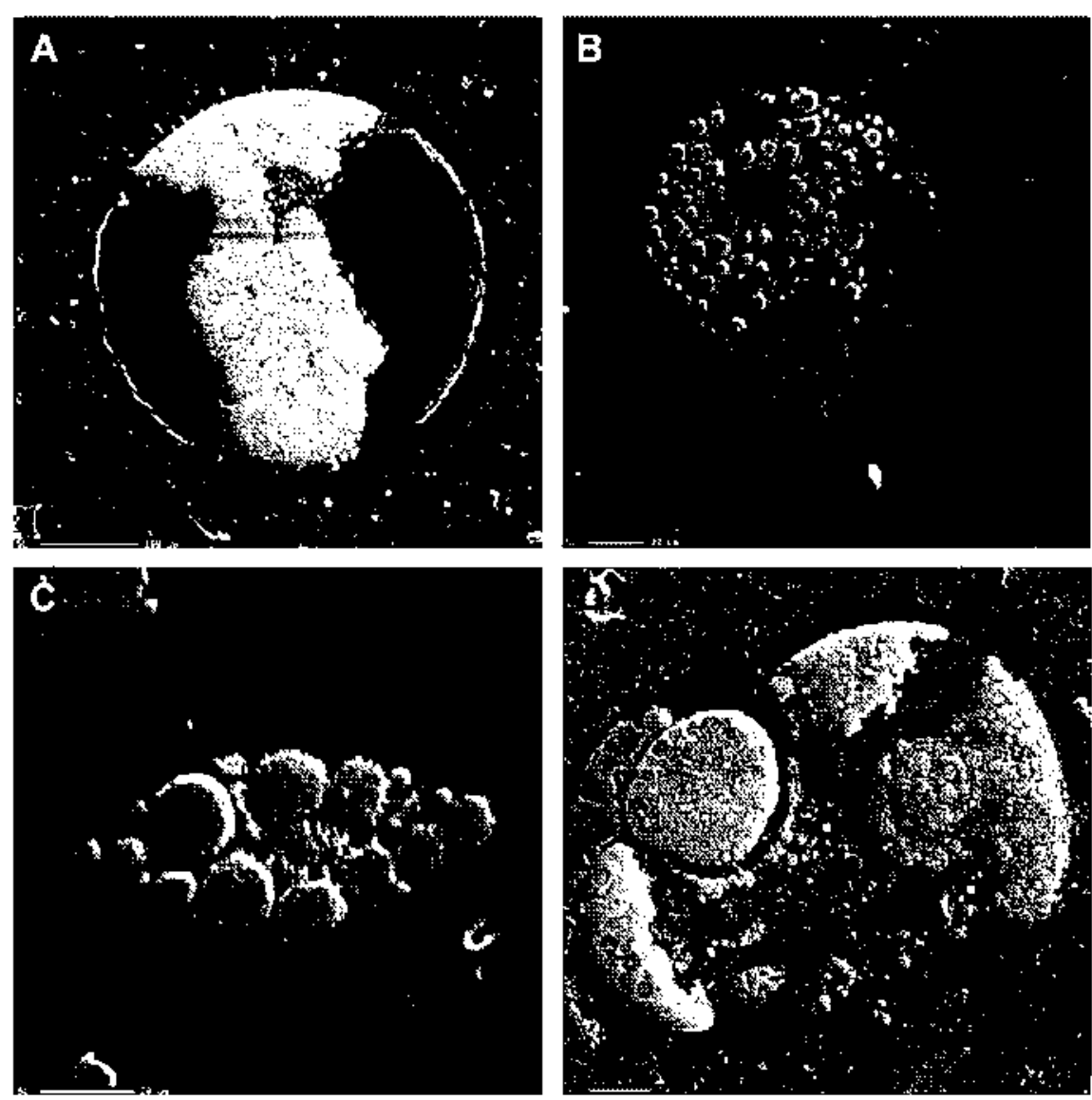

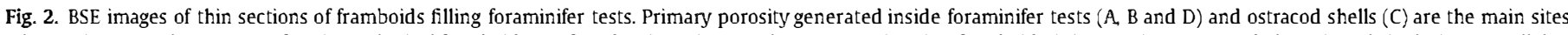

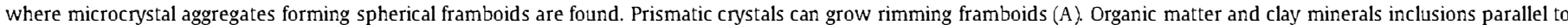
the crystal faces are formed in euhedral morphologies (B).

The Gulf of Cadiz (SW Iberia) contains active hydrocarbon-rich vents (Somoza et al., 2003), extensive mud volcanism, mud diapirism and authigenic carbonates (chimneys, slabs and crusts) with light carbon isolopes' composilions. These features have been interpreted as indicators of the existence of reduced compounds (particularly methane and hydrogen sulphide) on or immediately below the seafloor (Díaz-del-Río et al., 2003). Since the discovery of the carbonate chimneys in 2000 (Díaz-del-Río et al., 2001), main studies are concentrated on the possible genesis of these carbonate structures. The present article is particularly focussed on the study of iron mineralization, trying to determine its role in the general process of formation of the chimneys, as well as to understand the complex geobiological interactions in this and other similar extreme hydrocarbon-bearing submarine ecosystems.

\section{Materials and methods}

Samples were taken with a rectangular benthic-type dredge at mounds on the Gulf of Cadiz continental slope tluring 2000 and 2001 R/V Cornide de Saavedra cruises. A BENTHOS underwater camera was used to obtain bottom photographs. More than 200 carbonate chimneys were collected from four sites at depths ranging from 850 to $1100 \mathrm{~m}$ (ANASO0-DA10: $36^{\circ} 8^{\prime} \mathrm{N} / 7^{\circ} 43^{\prime} \mathrm{W}$; ANAS01-DA1: $36^{\circ} 06.96^{\prime} \mathrm{N} / 7^{\circ} 36.31^{\prime} \mathrm{W}_{\text {; }} \mathrm{DA2}: 36^{\circ} 06.48^{\prime} \mathrm{N} / 7^{\circ} 36.93^{\prime}$ W; DA15: $36^{\circ} 09.29^{\prime} \mathrm{N} / 7^{\circ} 32.89^{\prime} \mathrm{W}$ and DA18: $36^{\circ} 09.29^{\prime} \mathrm{N} / 7^{\circ} 32.89^{\prime}$ $W)$. Further details can be found in Díaz-del-Río et al. (2003). Chimneys show a wide variety of shapes and range in size from several centimetres to a few decimetres and consist of porous fine-grain carbonates (mainly Fe-rich dolomite) hosting quartz grains, Fe-Ti oxides and phyllosilicate grains, foraminifer tests and ostracod shells as main components.

From a set of 24 chimneys, six representative sperimens were selected for the analyses. Bulk mineralogy was determined using X-ray diffraction (XRD) on powder samples using a diffractometer with $\mathrm{Cu} \mathrm{K} \alpha$ radiation (Philips $\mathrm{PW}-1700$ ). Phillips ADP program and ICDD database are used for mineral identification. The genchemical composition of the bulk rock (major, minor and trace elements) was analysed by X-ray fluorescence using a spectrometer MagiX of l'ANanalytical with $\mathrm{Rh}$ tube and software $\mathrm{X}-40$.

In addition to the conventional study of thin and polished sections by transmitted and reflected light optic microscopy. a textural, compositional and mineralogical investigation of the samples was mate using a l'hilips $\times 120$ sranning electron microscope with accelerating voltages of $20-30 \mathrm{kV}$ and an electron microprobe WDS (EPMA, Electron Probe Micro Analyzer) JEOL mark and Superprobe JXA-8900M model (Electron Microscopy Centre "Luis Bru", Complutense University of Madrid). It is equipped with four wavelength dispersion spectrometers (four canals; where the following crystals are lodged: Channel 1, TAP and LDE2; Channel 2, PETJ and LIF; Channel 3, PETJ and LIF; Channel 4, PETJH and LIFH. A total of 250 punctual analyses were made with a difference of potential of $20 \mathrm{kV}$, a current intensity of $50 \mathrm{nA}$, with focussed beam and variable measure times, according to different elements, from 10 to $20 \mathrm{~s}$ in the sharp point, and from 5 to $10 \mathrm{~s}$ in the background point. The corrections of the intensities were made with ZAF matrixes. 

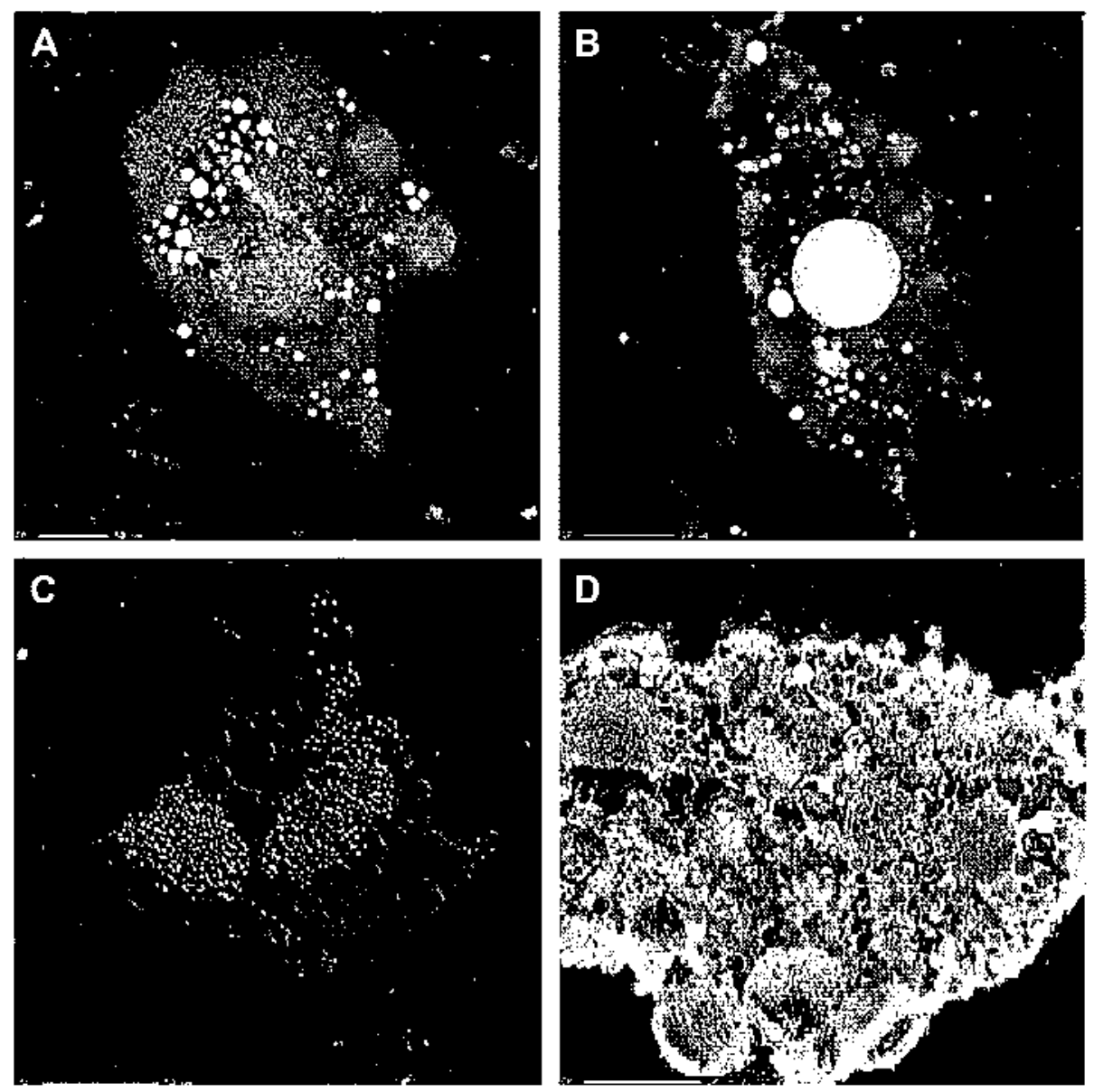

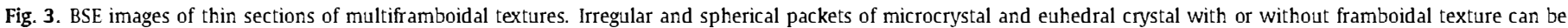
observed in multiframboidal textures.

\section{Results and discussion}

The carbonate chimneys which host the iron mineralization are mainly composed by Fe-rich dolomite and ankerite trace amounts of quartz, calcite and goethite were also detected. The whole-rock geochemistry of carbonate chimneys is summarized in Table 1.

\subsection{Iron mineralization: mineralogy and textures}

Primary porosity generated inside foraminifer chambers and ostracod shells often is filled with closely packed microcrystals of iron minerals forming framboids. Different morphologies are observed: from irregular morphologies and subspherical associations of microcrystals (framboids sensu stricto') to subeuhedral and euhedral crystals with or without internal mirmorystals (ligs. 1 and 2). In addition, multiframboidal textures are also found in the samples: mainly, groups of microcrystals, spherical framboids and euhedral crystals (Fig. 3). Microcrystals and euhedral crystals show cubic, octahedral and pyritohedral habits. Gnet hite is the principal mineral of the framboids and euhedral morphologies, and only one sample (sample 18220018-AN01) shows both goethite and pyrite forming framboids and euhedral crystals (Fig. 4). In this sample, the contents in $\mathrm{Fe}, \mathrm{V}, \mathrm{Ba}, \mathrm{Mn}, \mathrm{As}, \mathrm{Zn}, \mathrm{Ni}$ and $\mathrm{Co}$ are the lowest, and contents in $\mathrm{Si}, \mathrm{Ca}, \mathrm{P}$ and $\mathrm{Sr}$ are the highest (Table 1 ) with respect to the whole set of chimneys analysed.

In accordance with the well-known 'Ostwald rule', for low temperatures, framboidal pyrite growth is usually preceded by the formation of unstable iron monosulphides mackinawite (FeS) and greigite $\left(\mathrm{Fe}_{3} \mathrm{~S}_{4}\right)$, the least stable sulphide precipitating first (Rickard et al., 1995; Wilkin and Barnes, 1997). Transformation from greigite to pyrite may occur either by sulphur addition (Berner, 1984) or iron loss (Furukawa and Barnes, 1995) preserving the framboidal morphology.

Although few works are published about framboidal oxyhyclroxicles (Mucke et al., 1999) oxidation of framboidal pyrite is a common process (L.urher et al., 1982; Wilkin and Barnes, 1997). Pyrite oxidation studies (Huggins et al., 1980) showed that pyrite transforms first into szomolnokite $\left(\mathrm{FeSO}_{4} \cdot \mathrm{H}_{2} \mathrm{O}\right)$, then oxidizes to lepidocrocite $(\boldsymbol{\alpha}-\mathrm{FeO}(\mathrm{OH}))$, and passes finally to gnethite $(\gamma-\mathrm{FeO}(\mathrm{OH}))$. The oxyhydroxide habits, and its coexistence with iron sulphides in the same foraminifer remains in sample 18220018-AN01 ( $\mathrm{Fig} .4$ ), suggest goethite formation as the result of pseuclomorphism after pyrite.

\subsection{Crystal and framboid sizes}

The dimension of 196 framboids and euhedral rrystals was measured, with special attention to microcrystal, framboid and multiframboid sizes and the different crystal morphologies (see Table 2). Most framboids range from 5 to $20 \mu \mathrm{m}$ in size (Wilkin et al., 1996), although framboids as large as $250 \mu \mathrm{m}$ have occasionally been found (Sweeney and Kaplan, 1973). In our case, we have detected that the different scales of size and complexity of framboidal morphologies are related, as previously defined, to a continuous growth and rearrangement of framboids into euhedral crystals. Thus, in accordance with Sawlowicz (1993), euhedral 

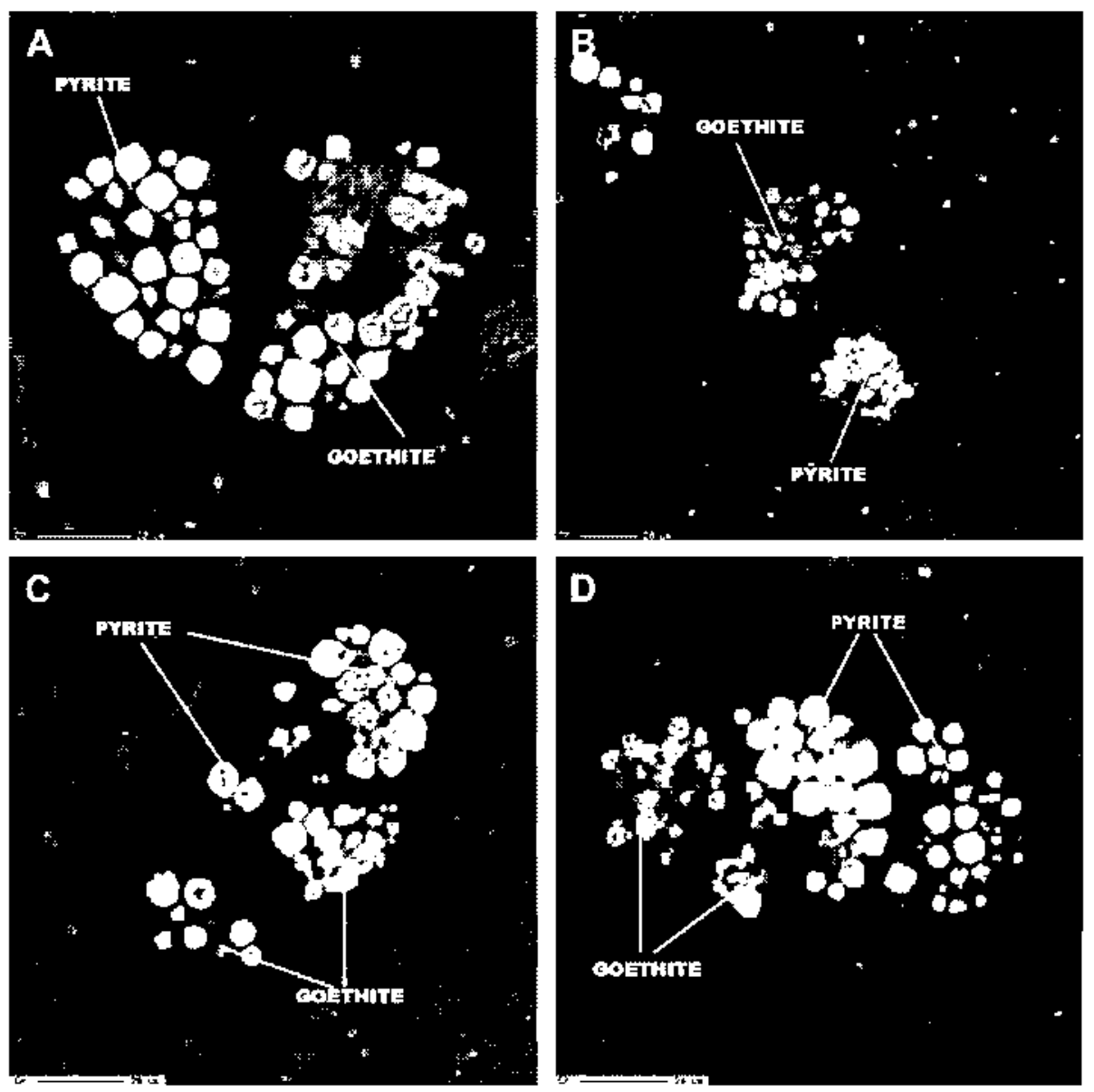

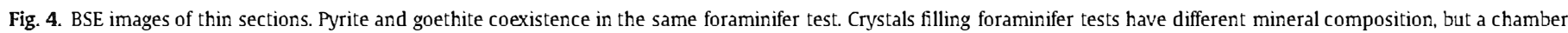
presents always the same mineralogy.

crystals are much more easily formed from microcrystals and framboids of small sizes than from multiframboid and large framboids, which explains the significant size differences with respect to the observed morpholngies.

\subsection{Iron minerals geochemistry}

Framboidal and euhedral goethite and pyrite were analysed by electron microprobe (see Section 2), paying special attention to crystal norphologies (Table 3). $\mathrm{Mg}, \mathrm{Si}, \mathrm{Al}, \mathrm{Ca}$ and $\mathrm{P}$ anomalies detected can be interpreted in connection with the existence of fine-grain carbonates, clay minerals and organic matter filling interstices in the framboids. The small grain size of the microcrystals (in our case, $143 \mathrm{~nm}$ of mean size) and the large effective surface of framboids make effective the ackorption of dissolved cations and inorganic anions, organic matter with fine-grain materials, iron oxides and clay minerals. As it has been demonstrated (Morse et al., 1987), adsorption or co-precipitation reactions play an important role in the control of trace metal concentrations in anoxic environments. Fiperially significant is the large concentration of Mo found in sulphide crystals. Mo is very mobile in the upper portion of the anoxic sediments, but is fixed in iron sulphicles at depth (Malcom, 1985), but it is released during the transformation of monosulphicles to pyrite. The presence of large concentrations of Mo in framboidal and euhedral pyrite (more than $11000 \mathrm{ppm}$ ) is indicative of the possible existence of previous monosulphicles phases (mackinawite and greigite) in the pyrite formation. Many trace metals have been found to be frequently associated with iron sulphides in anaerobic environments, including $\mathrm{Zn}, \mathrm{Pb}, \mathrm{Co}, \mathrm{Ni}$, As and occasionally $\mathrm{Mn}$. The association of the different trace metals varies in different environments. $\mathrm{Ni}$ and Co are strongly associated with sulphides, while $\mathrm{Zn}$ and Mo were

Table 2

Statistical data for crystal sizes measured in different crystal morphologies

\begin{tabular}{|c|c|c|c|c|c|c|}
\hline & $N$ & Mean $(\mu \mathrm{m})$ & Measured error $(\mu \mathrm{m})$ & Minimum $(\mu \mathrm{m})$ & Maximum $(\mu \mathrm{m})$ & Standard deviation \\
\hline Microcrystals & 106 & 1.4 & \pm 0.15 & 0.8 & 3.5 & 0.55 \\
\hline Framboids & 196 & 21.3 & \pm 0.28 & 5.5 & 59.1 & 12.79 \\
\hline Multiframboid & 157 & 131.8 & \pm 0.62 & 9.5 & 297.5 & 118.05 \\
\hline Irregular & 11 & 37.5 & \pm 3.07 & 18.6 & 56.1 & 10.19 \\
\hline Subspherical & 35 & 23.6 & \pm 2.05 & 7.5 & 59.1 & 12.15 \\
\hline Subeuhedral & 46 & 22.6 & \pm 1.58 & 9.2 & 49.0 & 10.72 \\
\hline Euhedral with microcrystals & 26 & 25.3 & \pm 1.94 & 5.5 & 50.9 & 9.89 \\
\hline Euhedral without microcrystals & 68 & 14.1 & \pm 0.97 & 5.9 & 48.3 & 7.97 \\
\hline
\end{tabular}




\begin{tabular}{|c|c|c|c|c|c|c|c|c|c|c|c|c|c|c|c|c|}
\hline Morphology & $\mathrm{Mg}$ & $\mathrm{Si}$ & $\mathrm{Al}$ & As & $P$ & $\mathrm{Ca}$ & V & $\mathrm{Ni}$ & Mo & Co & $\mathrm{Pb}$ & $\mathrm{Fe}$ & $\mathrm{S}$ & $\mathrm{Mn}$ & $\mathrm{Ti}$ & $\mathrm{Zn}$ \\
\hline Subspherical-irregular & 11629 & 7903 & 6005 & 1974 & 5724 & 7019 & 751 & 323 & 380 & 745 & 528 & 574613 & 287 & 569 & 246 & 393 \\
\hline Subeuhedral-euhedral & 10205 & 6728 & 5136 & 1227 & 5013 & 6589 & 508 & 271 & 360 & 729 & 514 & 581417 & 403 & 671 & 306 & 402 \\
\hline Difference & 1423 & 1175 & 869 & 747 & 711 & 430 & 243 & 52 & 20 & 17 & 14 & -6804 & -117 & -102 & -60 & -9 \\
\hline Pyrite & 1546 & 1726 & 909 & 403 & 388 & 6708 & 1376 & - & 11024 & 477 & 3395 & 506115 & 469437 & 209 & 127 & 268 \\
\hline Goethite & 14897 & 9637 & 2801 & 2246 & 5338 & 11989 & 812 & 282 & 329 & 674 & 677 & 604146 & 1678 & 323 & 137 & 321 \\
\hline Difference & 13351 & 7911 & 1892 & 1843 & 4950 & 5281 & 564 & 282 & 10695 & 197 & 2718 & 98031 & 467759 & 114 & 10 & 54 \\
\hline
\end{tabular}

more strongly bound by organic matter. As is specially associated with framboidal and noneuhedral pyrite ( $\mathrm{C}$ raham and Robertson, 1995; Ratnamohan et al., 1998). In the samples analysed Mo, $\mathrm{Pb}$ and $V$ are preferably associated with iron sulphides, and the other hand, As, Co, Mn and $\mathrm{Zn}$ are associated to iron oxylyydroxides (Table 3).

\subsection{Framboidal evolution}

Close spatial relationship between framboidal and euhedral was often observed in nature and suggests genetic relationship (Love, 1965; Kalliokoski, 1965; Love and Amstutz, 1966; Ostwald and England, 1977, 1979; Swalowicz, 1987, 1993). Multi-faceted framboids with regular arrangement of microcrystals represent the link between these two morphologies (Sawlowir\%, 1943). Love and Amstutz (1966) suggested the possibility of recrystallization from framboidal to single grain pyrite. Sawlowicz (1993) developed this suggestion and proposed a continuous growth of microcrystals in the framboids (sometimes towards euhedral crystals; as long as they are in contact with the initial solution. Martinez-Frías et al. (1997) defined a textural evolution pattern where framboids are progressively better faceted until they become euhedral in morpholngy. In the iron mineralization of the chimneys, some intermediate steps of this pattern occur, characterized by: (a) irregular morphologies (before framboid formation) and (b) micrncrystal arrangement and lose of framboidal texture (before transformation into euhedral crystals).

Although framboidal pyrite can be synthesized inorganically (Farrand, 1970; Butler et al., 2000), in natural sediments the chemical environment that is necessary for the formation of iron sulphides is created by sulphate-reducing bacteria activity (Berner, 1984). As indicated before, the growth and aggregation of microcrystals in framboidal-type associations represent the first stage of evolution, with formation of irregular morpholngies and spherical framboids. Further development of cubic, octahedral and pyritohedral habits is represented by subeuhedral morphologies and muli-faceted framboids (Fig. 5). Differentiation (or loss) of organic matter in internal crystal inclusions also occurs. This is significant, as final euhedral crystals are formed with complete loss of the framboidal texture and the expulsion of organir matter occupying interstitial sites (in many cases, organic matter inclusions parallel to the crystal faces are formed). Of course, it is also plausible that euhedral pyrite not always formed via framboid evolution, and, therefore, direct preripitation cannot be excluded. It is important to stress that in sites with availability of space, large size foraminifer chambers and porosity generated between clasts, multiframboidal textures are observed, and all the stages of textural evolution can be found. A continuous art ivily of sulphate-reduring bacteria, the iron and space availabilicy as well as the textural evolution could explain this coexistence.

Regarding the chemical element variations (Table 3), there are significant high concentrations of $\mathrm{Fe}, \mathrm{S}, \mathrm{Mn}$ and $\mathrm{Ti}$ and low concentrations of $\mathrm{Mg}, \mathrm{Si}, \mathrm{Al}, \mathrm{As}, \mathrm{P}, \mathrm{Ca}$ and $\mathrm{V}$ in subeuhedral and euhedral morphologies in comparison with subspherical and irregular morpholngies. These differences could be explained as a consequence of expulsion and differentiation of ine-grain carbonates, organic matter and clay elements during framboidal recrystallization.

\section{Conclusions}

The study of iron oxyhydroxide and sulphide mineralization occurred in hydrocarbon seep-related carbonate submarine chimneys of the Gulf of Cadiz reveals the presence of a great variety of morphologies, textures, mineralogy and geochemical concentrations.

Textural evolution (Fig. 5) consists of faces clevelopment with progressive loss of internal framboidal texture and mirrncrystal size increase. Growth of prismatic crystals rimming the framboids and formation of concentric inclusions of organic matter and clay minerals also occurred. The different scales of size and complexity of framboidal morpholngies are related to a continuous growth and rearrangement of framboids into euhedral crystals. Geochemical changes are linked to the textural evolution. Expulsion and differentiation of rine-grain carbonates, organic matter and clay elements during framboidal recrystallization causes a decrease in $\mathrm{Mg}$,

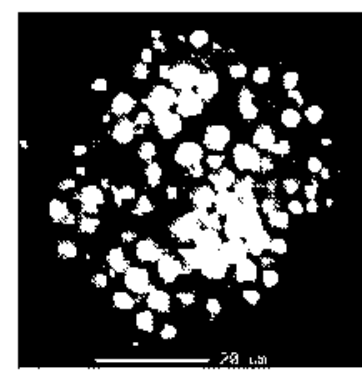

Irregular

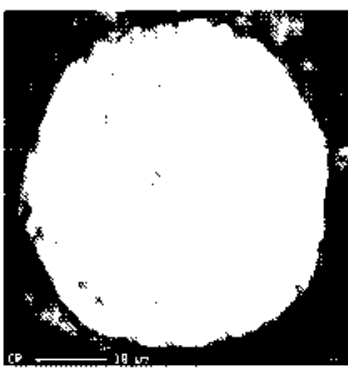

Spherical

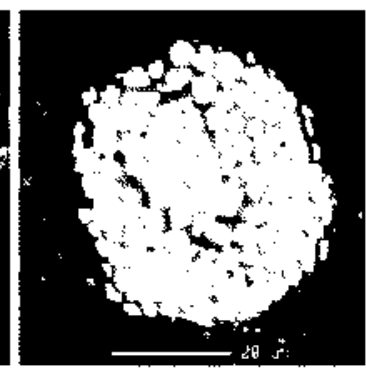

Subeuhedral

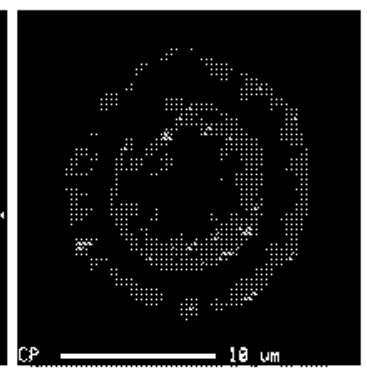

Euhedral with microcrystals

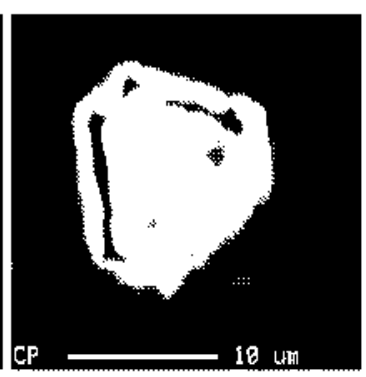

Euhedral without microcrystals

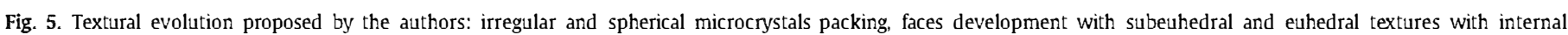

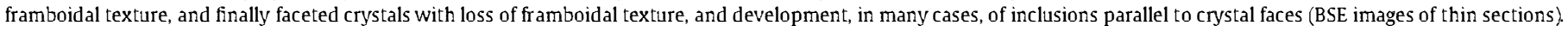


$\mathrm{Si}, \mathrm{Al}, \mathrm{As}, \mathrm{P}, \mathrm{Ca}$ and $\mathrm{V}$ concentrations with increase in $\mathrm{Fe}, \mathrm{S}, \mathrm{Mn}$ and Ti.

Iron oxylydroxides' habits and the coexistence with sulphicle crystals in the same sample are interpreted as a process of pseuclomorphism of goethite after pyrite with framboidal texture preservation and redistribution of some elements could take place. large concentrations of Mo in framboidal and euhedral pvrite could be related with previous monosulphicles phases.

Sulpluare-reducing bacteria activity is the principal way that provides geochemical conditions for iron sulphide precipistation in sedimentary environments with lower concentrations of oxygen (Berner, 1984). Thus, in the Gulf of Cadiz formation of authigenic carbonates and iron minerals filting porosity could be signals of anaerobic oxidation of methane and bacterial sulphate reduction. Likewise, the presence of multiple morphologies in the same sample. even in the same multiframboidal texture suggests a link between mineral evolution, iron and space availability and microorganisms activity.

\section{References}

Aloisi, G., Bolloubassi, I. Tleijs, S.K., Pancost, RD.. Pierre, C., Eamslc̆, J.s.s.,

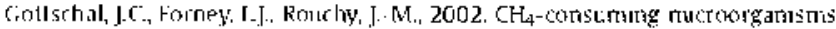
and the forrtation of car'jonate crusts at cold-seeps. farth and Planetary sience Letters 2013. 1955203

Barnes, KO., Goldjere. E.D., 1976. Methane production and consumption in anoxic marine sediments cieology 4, 237.300.

Berner. R.A., 1984. Sedimentary pyrite formation: an update. Cicochimica et Cosmoctimica Acla 48, 605-615.

Bian, I., Hintichs, K.-U., Xie. T., Brassell, S.C., Iversen, N., Fossing. II., Jergensen, B.B., Jayes. J.M., 2001. Algal and archaeal polyisoprenoids in a recent mariue seduntent: nulecular isotopic evidence for anaerobic oxidation of melhane. Geochemistry. Gcophysics and Geosystems 2, dor:10.1029:70006ronoll2.

Rusehorw, S.F., Blair, N.E., Ghanton, J.P., Martens, C.S., 1996. A mass Jalance of ${ }^{\circ} \mathrm{C}$ and ${ }^{12} \mathrm{C}$ in an organic-rich methane-producing marine scdimenl. licochimsta et Cosmochimica Arti 60, $38.75 \cdots 3848$.

Boetius, A., Ravenschlag, K.. Schubert, C.J. Rickert, D., Widdel, F., Cicseke, A., Amann, R. Jørgensen, B.B., Witte, U., Pfannkuche, O., 2000. A marine rricrubial consortium apparently mediating anaerobic oxidation of methane. Vatu:fe $4[1 \%$ $623-626$.

Bohrmann, G., Greinert, J., st:ess, E., Torres, M.E., 1998. Authigenic carbonates from the Cascadia subduction zone and their relation to gas hydrate stability. Gecilog: 26, 647-550.

Bchrmanת, G., Suess, E., Greinert, J., Teichert, B., Naehr, T., 2002. Gas hydrate riallonates frord Hydrate Fidge, Cascadia convergent margin: indicators of near-sealloor clathrate deposits. In: Proceedings of the Fourth International Cumlerence on Gas Hydrates, Yokoharia. pp. 102-107.

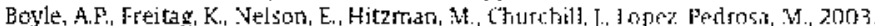

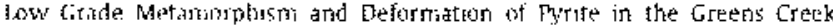

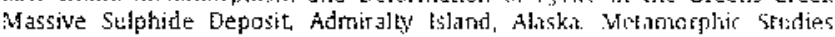

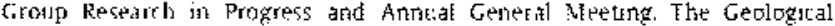
Saciely Butington House, London (Abstract)

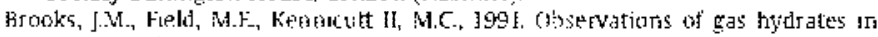

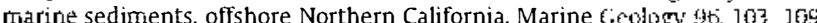

Butler, I., Rickard, D., 2000. Framboidal pyrite formation vin the oxidation of iron (13) monosulfide by hydiogen sulphide. Gecroinica et Cosmenchica Ma 64. 2665-2672.

Butler, I., Rickard, D., Grimes, S., 2000. Framboidal pyrite: selt organisation in the Fe-S systcm. Goldschmidt. Journal of Conference A.retrac $5 \overline{5}, 276-277$.

Cable, J.E., Burnet., W.C., Chanton, J.P., 1997. Magnitude and variations ol grou:nil water secpage along a Florida marine shoseline. Biogeochemistry 38, 189-205.

Chath.רn, 13.s., 1974. Daxgenetic pyrite from the lead-zinc deposits of Zawar. India. Mineralum Deposite 9, 69-73.

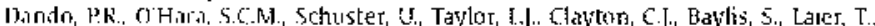
1994. Gas seepage from a carionate cemented sandslone reet on the katrects const of lenmink. Marine and Petrulecirn Geology 11. 182-189.

De Angelıs, M.A., Lilley. M.D., Olson, E.J., Baross, J.A., 1993. Methane oxid.atwon in decp-sca hydrolhermal plumes of the Findeavour Segment of the Juan de Fuca Rudge. Deep-Sea Research I 40, 1169-1186.

[DeLong, E.F. 2000. Resolving a methane mystery. Narute 407, $577-579$

Diaz del-kio, V., Sortwza, Ln, Martinez-Frías, J.. I [ernandez-Molina, F.J., I.un.r., R., Fernández-Fuga. M.C., Maestro, A., Terrint,i, P., t.live, F., Grurcia, A., Gatcia, A.C., Vázquez, J.T., 2001. Car'zonate chimneys' in the Gulf of Cadiz: inilial reporl of theis petrography and geochemistry. In: Final Proceedings of the International Conterence ol fiecological Processes un Deep.Water Eurupean Margins, Noscow, Rusila. UNESCO IOC Workshop Report 175, pp. 5.354.

Wiaz del Rio, V., Sormza, L. Martínez-Frias. I. Mata, M.P. Delgado, A. Ilernández-Molina, E.j., Lunar, R., Martín-Kubi, J.A., Macstro, A., Fernindez, Plg., M.C., Leớn, R., Ttave, F.., Medialdea, T. Văzoluez, J.T., 2003. Vast liclds ol

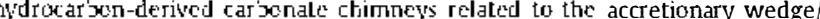
olistostrome of the dillf of Gitiz.. Marme Geology 195, 177-200.

Evertivi, A.. 1977. Origin ol lramboidal pyrite in clayey Holocene scdiments and in Jerassic blark stiale m the norliwestem paut of the Barents Sea Sedinientology 24. 591-595.

Elvert, M., Suess, E., Whiticar, M.J. 1999. Anaerobic methane oxictarion as5uciated with marine gas hydrates: superlight C-isotopes from saturated and

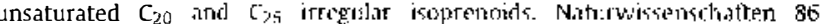
295-300

Elvert, M., Sisess, E., Greinert, J., Whiticar, M.J., 2000. Arclius mediating anaerobic methane oxidation in deep-sea sediments at cold seeps of the eastern Aleutian subduction zone. organic Cicocheristry $31,7175118 \%$

Farrand, M., 1970. Finmisintisl si:Ipliwites prepipitated synthetically. Mineralium Deposita 5, 237-247.

Fisukawh, Y., Burnes. H.L., 1995. Reactions fortring plirite from precipitated aniofphoes ferrous sulphide. In: Vairavamurthy, M.A., Schoonen, M.A.A. (Eds.) Ciectiemal Trinsformations of Sedimentary sulphur. Amierican Cherical Seliety Sympositm Series, vol. 12, pp. 194-205.

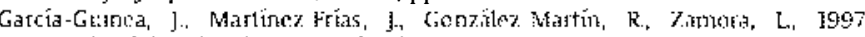
Eraniondal pyrites in antique books. Nature 388,631

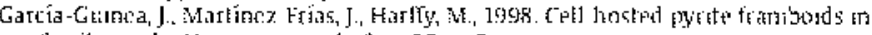
lossil woods. Naturwassenseliaften $85,1-5$.

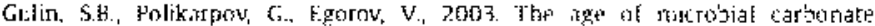
structures grown at methane seeps in the Black Sea unth an imiplication of daling of the seeping rocth ane. Warsine thematsy $84,67.72$

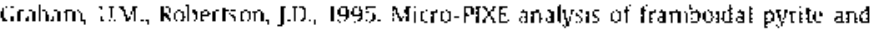
asscicialed maceral types in oil shale. Fuel 74,530-535.

$H$ an, X., Siless, F., siahling, H., W.1llmann, $K$, 2004. Flud venting activity on the Costa Rica margin: new results from authigenic carjonates. Internation.t] foum.al Fintli scrence $97,596,611$.

llinrichs, K.-U., Boebis. A., 2002. The anacrojic oxidation of methane: new insigtits

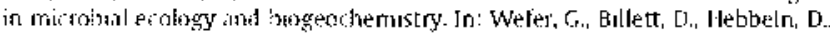
Turgensen, B.B., Schlüter, M., Van Weering. T. 'Eds.', Ocean Margin Syslems. ipringer Vrel.g. Berlin, pp. 45\% 4\%;

Hinrichs, K-U., llayes. J.M., Sylva, S.P., Brewer, P.G. DeLong, E. F, 1999. Methane.

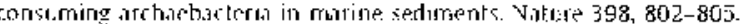

Hinrichis, K.-U., Summians, RE., Orphan. V., Syiva, S.P., Hayes, J.M.. 2000. Molcculas

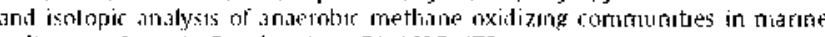
sediments. Organic Geochemistry 31, 1685-1701.

Horehler. T.M.. Alperin, M.J., AlberL D.B., Martins. C.S., 1994. Fiald and la'xorarory str:ties of methane oxudatwn in an anoxir. marine sediment: evidence tor a methanogen-sulfate redccer consortium. Global Biogeochernical cycles \&. 4.51433

Hübscher, C., Kukowski, N., 2003. Complex BSR pattern in the Yaquina Basin off Peru. Geo-Marine Letters 23, 9]-J01

Huggins, F.E., Huffman, G.P., Kosmach, D.A., Lowenhaupt, D.F., I980. Mössauer

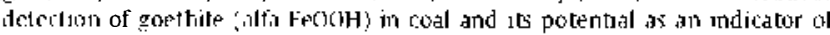
coal oxidation. International Journal of Coal Geology 1. \% $\%$. 1 .

Ivanov, M.V., Polikarpov, G.G., I ein, A.Yv., Galchenko, V.F., Egorrs, V.N., Gulin, S.B. Gulin, M.B., Rusanov, I.I., Miller. Y.M. Kuptsov, V.1., 1991. liogeochemistry of carbon cycle at the methane seeps of the Black Sea. Proceedings af Acaderny of Sciences of USSR 320, 1235-1240 (in Russian).

Jørgensen, N.O., 1992. Methane derived carbonate cementation of riarine sediments from the Kattegat. Denmark: geochemical and geological evidence. Marine Geology 103, 1-13.

Kalliokoski, J., 19i. Framboids: colloid-crystals of pyrite (abstract). Economic Geology 60, 1562.

Laier, T., Jørgensen, v.O., Burchard, B., Cederberg, T., Ku.jipers. A., 1992. Accumulation and seepages of biogenic gas in northern Denmark. Continental Shelf Research $12,17 \% 3 \quad 1186$.

Lanoil, B.D., Sassen, R., La DLix, M.T., Street, S. Nealson, K.H., 2001. Bacteria and archaea physually ascascoted with Getll of Mexico gas hydrates. Applied and Environmental Microbiology 67, 5143-5153.

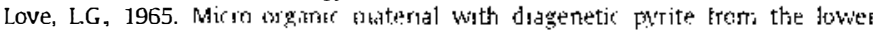

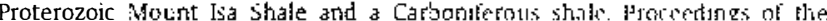
Yorkshire Geological Siccetty 35, 187-201

Love, L.G., Amstutz, G.C., 1960. Revew of nicrosctpus pyrite from, the Devonian

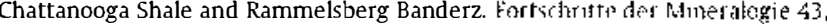
277-309.

Love, L.G. Amstutz, G.C., 1969. Framboidal pyrite in two andesites. Neues Jahrbuch für Mineralogie - A'bandlu:ngen 3, 97-108.

Love, L.G, 1971. Early diagenetic polyframboidal pyrrite, primaty and redeposited from the Wenlockian Jjenlyggh Grit Gruup, Cunway, North Wales, U.K Journal of Sedirientary Petrolagy 41, ]038-1044.

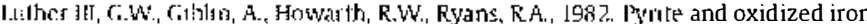
mineral phases forried from pyrite oxidation in sall marsh and estrarine

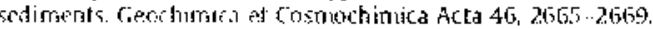

Malcom, S.J., 1985. Early diagenes is of molybdentm in esluarine sodinemls. Marine Chicmistry 15, 21327.5

Nasian, M., 1974. Frambaidal pyrite in concretions. Mineralem Deposila 9, 8\%.8. Martinez-Frias. J.. Navarce. A., Lenar. R, log7. First reference of nysite frumboids in a $\mathrm{Hg}$. Sta mineralıztion: the Valle del Azogue mineral deposit (SE Spain). Vaxies Jatırouch fër Mincralogie - Abhandlungen 4, 175 184.

Nolmeris, R., Lunar, R., Martinez-Frías, J. Somoza. L, Diaz-del-Rio, V., 2005. Bio mineralizacioncs melti-framboidales en chimeneas sı:lmmarınas metanógenas (Golfo de Cid17.i. Mac la 3, 135..137. 
Merinero, R., Lunar, R, Martínez-Frías, J., Somoza, L., Díaz-del-Río, V., 2006. Ironrich coccoidal microcrystals and framboids in submarine, methane-derived carbonate chimneys (Gulf of Cadiz, SW Iberian Peninsula): mineralogy, textures and astrobiological relevance. Geophysical Research Abstracts 8, 01382.

Michaelis, W., Seifert, R., Nauhaus, K., Trude, T, Thiel, V., Blumenberg, M., Knittel, K. Gieseke, A., Peterknecht, K., Pape, T., Boetius, A., Amann, R., Jørgensen, B.B. Widdel, F., Pechmann, J., Pimenov, N.V., Gulin, M.B., 2002. Microbial reefs in the Black Sea fueled by anaerobic oxidation of methane. Science 297, 1013-1015.

Morse, J.W., Millero, F.J., Cornwell, J.C., Rickard, D., 1987. The chemistry of hydrogen sulphide and iron sulphide systems in natural waters. Earth-Science Reviews $24,1-42$

Mucke, A., Badejoko, T.A, Akande, S.O., 1999. Petrographic-microchemical studies and origin of the Agbaja Phanerozoic Ironstone formation, Nupe Basin, Nigeria: a product of a ferruginized ooidal kaolin precursor not identical to the Minettetype. Mineralium Deposita 34, 284-296.

Naehr, T.H., Rodriguez, N.M., Bohrmann, G., Paull, C.K., Botz, R, 2000. Methanederived authigenic carbonates associated with gas hydrate decomposition and fluid venting above the Blake Ridge Diapir. In: Paull, C.K, Matsumoto, R, Wallace, P.J., Dillon, W.P. (Eds.), Proceedings of the Ocean Drilling Program Scientific Results, vol. 164. Ocean Drilling Program, College Station, Texas, pp. 285-300.

Nauhaus, K., Boetius, A., Krüger, M., Widdel, F, 2002. In vitro demonstration of anaerobic oxidation of methane coupled to sulphate reduction in sediment from a marine gas hydrate area. Environmental Microbiology 4, 296-305.

Orphan, V.J., House, C.H, Hinrichs, K.-U, McKeegan, K.D., DeLong, E.F., 2001. Methane-consuming archaea revealed by directly coupled isotopic and phylogenetic analysis. Science 293, 484-487.

Orphan, V.J., House, C.H., Hinrichs, K.-U., McKeegan, K.D, DeLong, E.F., 2002. Multiple archaeal groups mediate methane oxidation in anoxic cold seep sediments. Proceedings of the National Academy of Sciences 99, 7663-7668.

Orpin, A.R., 1997. Dolomite chimneys as possible evidence of coastal fluid expulsion uppermost Otago continental slope, southern New Zealand. Marine Geology 138, 51-67.

Ostwald, J., England, B.M., 1977. Notes on framboidal pyrite from Allandale New South Wales, Australia. Mineralium Deposita 12, 111-116.

Ostwald, J., England, B.M., 1979. The relationship between euhedral and framboidal pyrite in base metal sulphide ores. Mineral Magmatic 43, 297-300.

Pancost, RD, Sinninghe Damsté, J.S., de Lint, S., van der Maarel, M.J., Gottschal, J.C., The Medinaut Shipboard Scientific Party, 2000. Biomarker evidence for widespread anaerobic oxidation in Mediterranean sediments by a consortium of methanogenic archaea and bacteria. Applied and Environmental Microbiology 66, 1126-1132.

Pancost, R.D., Hopmans, E.C., Sinninghe Damsté, J.S., The Medinaut Shipboard Scientific Party, 2001. Archaeal lipids in Mediterranean cold seeps: molecular proxies for anaerobic methane oxidation. Geochimica et Cosmochimica Acta 65 1611-1627.

Paull, C.K., Neumann, A.C., 1987. Continental margin brine seeps: their geological consequences. Geology 15, 545-548.

Paull, C.K., Chanton, J.P., Neumann, A.C., Coston, J.A., Martens, C.S, Showers, W. 1992. Indicators of methane-derived carbonates and chemosynthetic organic carbon deposits: examples from the Florida Escarpment. Palaios 7, 361-375.

Paull, C.K., Ussler III, W., Borowski, W.S., Spiess, F.N., 1995. Methane-rich plumes on the Carolina continental rise: associations with gas hydrates. Geology 23, 89-92.

Paull, C.K., Schlining, B., Ussler III, W., Paduan, J.B., Caress, D., Greene, H.G., 2005. Distribution of chemosynthetic biological communities in Monterey Bay, California. Geology 33, 85-88.

Peckmann, J., Reimer, A., Luth, U., Luth, C., Hansen, B.T., Heinicke, C., Hoefs, J. Reitner, J., 2001. Methane-derived carbonates and authigenic pyrite from the northwestern Black Sea. Marine Geology 177, 129-150.

Pierre, C., Rouchy, J.M, Gaudichet, A., 2000. Diagenesis in the gas hydrate sediments of the Blake Ridge: mineralogy and stable isotope compositions of the carbonate and sulfide minerals. In: Paull, C.K., Matsumoto, R, Wallace, P.J. Dillon, W.P. (Eds.), Proceedings of the Ocean Drilling Program. Scientific Results, vol. 164. Ocean Drilling Program, College Station, Texas, pp. 139-146.

Ratnamohan, V.M., Cunningham, A.L, Rawlinson, W.D. Mukhopadhyay, P.K. Goodarzi, F., Crandlemire, A.L, Gillis, K.S., Macneil, D.J., Smith, W.D., 1998 Comparison of coal composition and elemental distribution in selected seams of the Sydney and Stellarton Basins, Nova Scotia, Eastern Canada. International Journal of Coal Geology 37, 113-141.

Rickard, D.T, Schoonen, M.A.A., Luther III, G.W, 1995. Chemistry of iron sulfides in sedimentary environments. In: Vair avamurthy, M.A., Schoonen, M.AA. (Eds.) Geochemical Transformations of Sedimentary Sulphur. American Chemical Society Symposium Series, vol. 612, pp. 168-193.
Ritger, S., Carson, B., Suess, E., 1987. Methane-derived authigenic carbonates formed by subduction-induced pore-water expulsion along the Oregon/Washington margin. Geological Society of America Bulletin 98, 147-156.

Roberts, A.P., Jiang, W.T, Florindo, F., Horng, Ch.-S., Laj, C., 2005. Assessing the timing of greigite formation and the reliability of the Upper Olduvai polarity transition record from the Crostolo River, Italy. Geophysical Research Letters 32 , doi: 10.1029/2004GL022137.

Sassen, R, Roberts, H.H., Carney, R., Milkov, A.V., DeFreitas, D.A., Lanoile, B., Zhang, C., 2004. Free hydrocarbon gas, gas hydrate, and authigenic minerals in chemosynthetic communities of the northern Gulf of Mexico continental slope: relation to microbial processes. Chemical Geology 205, 195-217.

Sawlowicz, Z., 1987. Framboidal pyrite from the metamorphic Radzimowice Schists of Stara Gora (Lower Silesia, Poland). Mineralogia Polonica 18, 57-67.

Sawlowicz, Z, 1993. Pyrite framboids and their development: a new conceptual mechanism. Geologische Rundschau 82, 148-156.

Sawlowicz, Z, 2000. Framboids: from their origin to application. Prace Mineralogiczne 88, 1-80.

Schieber, J., Baird, G., 2001. On the origin and significance of pyrite spheres in Devonian black shales of North America. Journal of Sedimentary Research 71, 155-166.

Schoonen, M.A.A., 2004. Mechanisms of sedimentary pyrite formation. In: GSA Special Paper, vol. 379, pp. 117-134

Shnukov, E.F., Sobolevskiy, Yu.V., Kutniy, V.A., 1995. Unusual carbonate buildups at continental slope of the north-western Black Sea - an apparent consequence of the degassing of sediments. Lithology and Minerals Resources. (Litologiya i Poleznye Iskopaemye, Moscow, Russia) 5, 461-541 (in Russian).

Somoza, L. Díaz-del-Río, V., León, R. Ivanov, M., Fernández-Puga, M.C., Gardner, J.M. Hernandez-Molina, F.J., Pinheiro, L.M., Rodero, J., Lobato, A., Maestro, A., Vázquez, J.T., Medialdea, T., Fernández-Salas, L.M., 2003. Seabed morphology and hydrocarbon seepage in the Gulf of Cádiz mud volcano area: acoustic imagery, multibeam and ultra-high resolution seismic data. Marine Geology 195, $153-176$.

Stakes, D.S., Orange, D., Paduan, J.B., Salamy, K.A., Maher, N., 1999. Cold-seeps and authigenic carbonate formation in Monterey Bay, California. Marine Geology 159, 93-109.

Suess, E., Bohrmann, G., von Huene, R., Linke, P., Wallmann, K., Lammers, S. Sahling, H., Winckler, G., Lutz, R.A., Orange, D., 1998. Fluid venting in the eastern Aleutian subduction zone. Journal of Geophysical Research 103, 2597-2614.

Sweeney, R.E. Kaplan, I.R., 1973. Pyrite framboid formation: laboratory synthesis and marine sediments. Economic Geology 68, 618-634.

Taylor, G.R, 1982. A mechanism for framboid formation as illustrated by a volcanic exhalative sediment. Mineralium Deposita 17, 23-36.

Teichert, B.M.A., Bohrmann, G., Suess, E, 2005. Chemoherms on Hydrate Ridge unique microbially-mediated carbonate build-ups growing into the water column. Palaeogeography, Palaeoclimatology, Palaeoecology 227, 67-85.

Teske, A., Hinrichs, K.-U, Edgcomb, V., de Vera Gomez, A., Kysela, D., Sylva, S.P. Sogin, M.L. Jannasch, H.W., 2002. Microbial diversity of hydrothermal sediments in the Guaymas Basin: evidence for anaerobic methanotrophic communities. Applied and Environmental Microbiology 68, 1994-2007.

Thiel, V., Peckmann, J., Seifert, R, Wehrung, P., Reitner, J., Michaelis, W., 1999. Highly isotopically depleted isoprenoids: molecular markers for ancient methane venting. Geochimica et Cosmochimica Acta 63, 3959-3966.

Thiel, V., Peckmann, J., Richnow, H.H., Luth, U., Reitner, J., Michaelis, W., 2001. Molecular signals for anaerobic methane oxidation in Black Sea seep carbonates and a microbial mat Marine Chemistry 73, 97-112.

Thomsen, T.R. Finster, K., Ramsing, N.B., 2001. Biogeochemical and molecular signatures of anaerobic methane oxidation in a marine sediment. Applied and Environmental Microbiology 67, 1646-1656.

Valentine, D.L., 2002. Biogeochemistry and microbial ecology of methane oxidation in anoxic environments: a review. Antonie Van Leeuwenhoek 81, 271-282.

Valentine, D.L, Reeburgh, W.S., 2000. New perspectives on anaerobic methane oxidation. Environmental Microbiology 2, 477-484.

Whiticar, M.J., Werner, F., 1991. Pockmarks: submarine vents of natural gas or freshwater seeps? Geo-Marine Letters 1, 193-199.

Wilkin, R.T., Barnes, H.L, Brantley, S.L, 1996. The size distribution of framboidal pyrite in modern sediments: an indicator of redox conditions. Geochimica et Cosmochimica Acta 60, 3897-3912.

Wilkin, RT., Barnes, H.L, 1997. Formation processes of framboidal pyrite. Geochimica et Cosmochimica Acta 61, 323-339.

Zhang, C.L., Li, Y., Wall, J.D., Larsen, L, Sassen, R, Huang, Y., Wang, Y., Peacock, A., White, D.C., Horita, J., Cole, D.R., 2002. Lipid and carbon isotopic evidence of methane-oxidizing and sulfate-reducing bacteria in association with gas hydrates from the Gulf of Mexico. Geology 30, 239-242. 